Pregledni naučni članak

UDK: 725.5(497.11)"18/19"

ID: 212273932

\author{
Mirjana Roter Blagojević \\ Vanredni profesor, Departman za arhitekturu \\ Arhitektonski fakultet, Univerzitet u Beogradu \\ Bulevar kralja Aleksandra 73/II, 11000 Beograd, Srbija \\ roterm@arh.bg.ac.rs
}

\title{
NASTANAK PRVIH ZDRAVSTVENIH KOMPLEKSA I ZGRADA U BEOGRADU U XIX I POČETKOM XX VEKA*
}

\begin{abstract}
Apstrakt: U radu se kroz analizu raspoložive građe i literature daje prikaz uslova izgradnje i arhitektonskih karakteristika zdravstvenih ustanova podignutih u Beogradu tokom XIX i početkom XX veka. Cilj je da se kroz prikaz izgradnje prvih zdravstvenih zgrada u Beogradu istakne značaj ove vrste državnih zdanja za modernizaciju obnovljene Kneževine Srbije i dostizanje evropskih standarda. U radu su analizirani uslovi njihove izgradnje, urbane i arhitektonske karakteristike, kao i značaj za uobličavanje karaktera i podsticanje razvoja okolnog ambijenta i utemeljenje modernog lika grada. Pored najznačajnijih državnih zdanja u Sava-mali - Sovjeta, Dvora i Velike kasarne, knez Miloš Obrenović 1837. godine započinje izgradnju Palilulske kasarne, u blizini velike česme na Palilulskom trgu. U sklopu kompleksa kasarne inicirana je izgradnja soldatečeskog špitala za stotinu bolesnika, čime započinje istorija izgradnje državnih bolničkih zgrada u obnovljenoj Kneževini. Bolnica je locirana u novim perifernim delovima grada koje naseljava srpsko stanovništvo, izvan stare utvrđene Varoši u šancu, što je bio pogodan prirodni položaj za zdravstvenu zgradu, na ozelenjenoj padini ka Dunavu, a obezbeđeni su i zdravi uslovi za njeno korišćenje, jer je u blizini bio kvalitetni izvor pijaće vode. Krajem četrdesetih godina, u vreme kneza Aleksandra I Karađorđevića, $\mathrm{u}$ novoproglašenoj srpskoj prestonici započinju pripreme za izgradnju Nove vojne bolnice, verovatno prema planovima glavnog praviteljstvenog indžinira, arhitekte Jana Nevole. Bolnica, predviđena za smeštaj 120 bolesnika, podignuta je na Vračaru 1846-49. godine, kod današnjeg Cvetnog trga, u blizini brojnih vojnih zgrada. Kao i njegovi prethodnici, knez Mihailo Obrenović je svoju vladavinu obeležio izgradnjom zdrastvene ustanove - prve civilne bolnice u Kneževini. Na placu u Vidinskoj ulici, koji je knez poklonio državi, kod Palilulskog trga i stare Palilulske kasarne, izgrađena je 1868. godine Varoška bolnica preme projektu državnog inženjera Jovana (Josifa)

\footnotetext{
* Rad predstavlja rezultat naučno-istraživačkog projekta br. 177009: "Modernizacija zapadnog Balkana", finansiranog od strane Ministratsva prosvete, nauke i tehnološkog razvoja Republike Srbije.
} 
Francla. Na samom početku novog veka, oko 1903-04. godine, u Beogradu je započeta izgradnja velikog kompleksa nove Vojne bolnice na zapadnom Vračaru, prema projektu Danila Vladisavljevića. Struktuiran po paviljonskom sistemu, kompleks je bio nukleus kasnijeg kompleksa Državne bolnice, koji je bio proširivan tokom prve polovine XX veka brojnim novim zgradama. Njegovim podizanjem srpska država je nakon jednog veka ostvarila nastojanja da nivo zdravstvene zaštite približi razvijenim evropskim državama.

Ključne reči: istorija, modernizacija, bolnice, arhitektura $\mathrm{Ne} \mathrm{MeSH}$ : urbani kontekst

Key words: history, modernization, hospitals, architecture Non MeSH: urban context

\section{Uvod}

Uspostavljanjem delimične državne nezavisnosti Kneževine Srbije hatišerifima iz 1829, 1830. i 1833. godine, stvoreni su uslovi za formiranje prvih državnih upravnih i zakonodavnih ustanova, uspostavljanje narodne skupštine, ministarstava i sudske vlasti, organizovanje policije i narodne vojske, obnovu crkava i manastira i dr. [1: 114-115.] Taj proces je zahtevao obnovu starih i izgradnju brojnih novih zgrada za njihov smeštaj. One su bile skoncentrisane u većim varošima, tadašnjoj prestonici Kragujevcu, ali i u Beogradu, Požarevcu i Šapcu. Pored reperezentativnih dvoraca, podizana su i raznovrsna zdanja za smeštaj državne administracije, vojnih, zdravstvenih, obrazovnih, kulturnih, saobraćajnih i drugih ustanova - carinarnica, kasarni, bolnica, škola, mehana, menzulana, prvih industrijskih postrojenja i sl. [2: 147. 3:66-118.]

Obnovljena Kneževina je privlačila brojno srpsko stanovništvo iz Vojvodine, Južne Srbije i ostalih krajeva pod osmanskom vlašću, koje je masovno naseljavalo posede koje je napuštalo tursko stanovništvo. Doseljeni Srbi iz Vojvodine uglavnom su činili obrazovaniji činovnički sloj građanskog društva u nastajanju. Pored njih uselio se veliki broj zanatlija i trgovaca, posebno grčko-cincarskog porekla iz oblasti Vardara, koji su doprineli razvoju privrede. [4: 54-55.] Geostrateški položaj Beograda, na granici ka zapadu i Austrijskoj carevini, kao i činjenica da se u njemu nalazilo sedište turske uprave za Beogradski pašaluk, uticali su da je grad imao poseban politički, vojni, saobraćajni i ekonomski značaj za Kneževinu. Prvi podaci o ukupnom stanovništvu u staroj beogradskoj Varoši govore da je 1838. godine u njoj živelo 12.963 stanovnika (8.483 hrišćana, 2.700 Turaka, 1.500 Jevreja i 250 stranaca). [5: 271.] Varoš je bila opasana zemljanim bedemom i rovom -šancem, a u nju se ulazilo kroz gradske kapije koje je kontrolisala turska vojna posada. Izvan bedema su, već od početka XVIII veka i austrijske rekonstrukcije, formirana nova naselja, sela -Savska varoš u priobalju, na Limanu (pristaništu); Sava-mahala, nekadašnja Srpska donja varoš; i Palulula, austrijsko naselje Karlštal, ispod Tašmajdana, sa srpskim 
grobljem i starom crkvom sv. Marka. Potez između Sava-male i Palilule, duž Carigradskog druma i okoline stare Batal džamije (danas deo Bulevara kralja Aleksandra od Terazija do Takovske ulice) je prema rečima savremenika bio pust i neizgrađen prostor. [6: 5.]

Veliki priliv stanovništva i nemogućnost da se uspostavi srpska vlast u staroj utvrđenoj Varoši, uticali su da knez Miloš Obrenović oko 1834. godine započne pripreme za izgradnju novog srpskog Beograda, koji će postati glavna varoš. Ona će nastati upravo na prostoru Sava-mahale zbog njenog povoljnog prirodnog položaja, na širokim, blago zatalasanim, osunčanim zapadnim padinama ka Savi, i dobrog saobraćajnog položaja, uz Topčiderski drum i put za Kumodraž, koji su je povezivali sa dvorskim kompleksom u Topčideru i srpskim delom starog utvrđenog naselja kod Varoš-kapije, ali i sa unutrašnjošću zemlje. Ubrzo započenje regulacija Abadžijske i Savamalske ulice (danas Kraljice Marije i Gavrila Principa), kao i izgradnja reprezentativnih državnih zdanja, nove kneževe rezidencije - Dvorca, skupštinskog doma - Praviteljstvujuščeg Sovjeta i Velike kasarne. [4: 81-82.] Podignuta su tokom 183536. godine, na prostoru oko raskrsnice današnjih ulica Kneza Miloša i Nemanjine, čime je utemeljen novi administrativni centar države, koji je zadržao upravnu i vojnu funkciju do današnjeg doba. [2: 146-147, 158. 3: 7684. 6: 8-10.] Moderna, zapadnjačka, pravilna mreža ulica, postepeno je prekrila padine zapadnog Vračara, o čemu svedoči sačuvani plan prvog državnog inženjera Franca Jankea iz 1842. godine, na kom su osim novih ulica ucrtana i nova reprezentativna državna zdanja. [4:

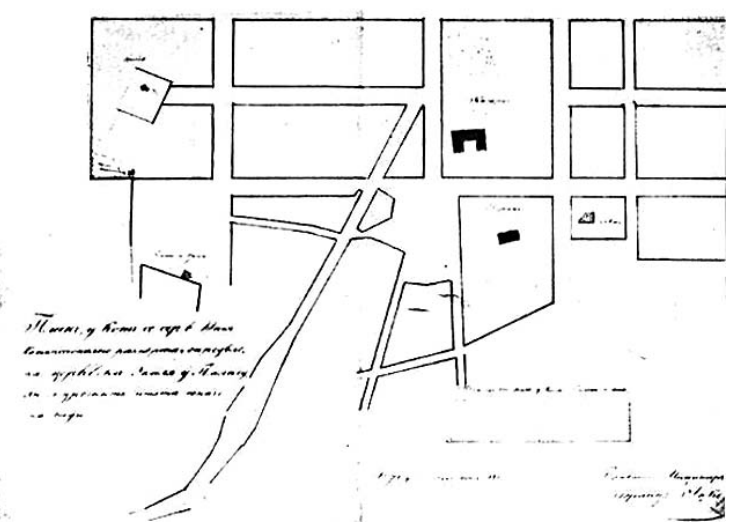
82, 84. 6: 10. 15: 174.] (Slika 1)

Regulacijom prostora zapadnog Vračara, knez Miloš je i u Beogradu, kao i u drugim naseljima u unutrašnjosti zemlje, započeo osnivanje novih varoši ili njihovih delova, želeći da sprovede osavremenjavanje i urbanizaciju kroz primenu racionalne klasicističke sheme, po ugledu na varoši u Austrijskoj carevini. [4: 13-26.] Od tog trenutka započinje prihvatanje modernih zapadnjačkih ideja u svim sferama javnog života Kneževine, sa namerom da se dostigne nivo razvoja srednjoevropskih država i unapredi život srpskog naroda, ali i izbrišu tragovi viševekovne turske vlasti. Međutim, proces modernizacije, urbanizacije i izgradnje svih vrsta javnih građevina, između ostalog i zdravstvenih ustanova, bio je tokom celog XIX veka usporavan veoma lošim opštim političkim, društvenim i ekonomskim prilikama u državi, koje su bile izazvanim ratovima. Sve do osamdesetih godina XIX veka izgrađen je veoma mali broj državnih zdanja različitih namena, a među njima je bio i relativno malo bilo vojnih i civilnih bolnica. [7:13-60.] 


\section{Prvi lekari i vojne bolnice početkom XIX veka}

Posebno je prvi period modernizacije države i uspostavljanja državnih i društvenih ustanova (1830-1839) bio opterećen brojnim teškoćama. Jedna od oblasti kojoj je bilo neophodno unapređenje bila je zdravstvena zaštita stanovništva i vojske. Civilnih bolnica nije bilo, a lečenjem stanovništva su se bavili priučeni samouci, tzv. travari, vidari, hećimi i sl., kao i turske hodže, jevrejski vidari i putujući grčki lekari iz oblasti Epira. U Beogradu je bio poznat Hećim Toma Kostić koji je držao mehanu u Varoši, preko puta srpske crkve (danas Kafana kod ,?”). [8: 793.] Lekovi su dobavljani iz Turske ili Austrije, a prodavani su po dućanima. Početkom dvadesetih godina u službi kneza Miloša je bio Konstantin Aleksandridi, doktor medicine, a zatim je od 1822. godine lični knežev lekar bio Napolitanac Vito Romita, visoki i ugledan Talijan, prethodno do 1823. godine lični lekar beogradskog vezira, inače samouki lekar sa juga Italije, koji je službovao u Carigradu i Bukureštu. [2: 141-142. 9: 24-25.10: 171.]

Romita je od vezira dobio zemljište od oko 6,5 hektara, daleko van Utvrđene varoši, na osunčanim padinama zapadnog Vračara, u kraju zvanom Guberevac. [11: 264, 266.] Tu je, nakon prelaska u kneževu službu, podigao svoju kuću, jednu od najsolidnijih građevina u tadašnjoj Kneževini, okruženu povrtnjakom, voćnjakom i vinogradom, sa sadnicama naručivanim iz Italije. [2: 141-142.] Izgrađena 1824. godine, bila je to jedna od prvih jednospratnih zgrada od masivne konstrukcije u beogradskoj varoši. [3: 63-64.] Kako je građena na sprat, zbog visine, kubične zatvorene strukture i masivnih zidova od kamena i opeke, izazvala je podozrenje Turaka, koji su tražili da se završi u bondruku, jer im je ličila na malo utvrđenje na dobrom strateškom mestu, sa pogledom na Tvrđavu i puteve koji vode ka njoj. I narod ju je zvao Doktorova kula, jer je podsećala na srednjovekovne kamene branič kule i zgrade za stanovanje sa odbrambenom namenom. [2: 141-142.] Međutim, ona je prvenstveno bila plod klasične italijanske tradicije, nalik rustičnim vilama na seoskim imanjima građenim $\mathrm{u}$ doba renesanse. Mada je njen centralni plan sa velikom prostorijom $\mathrm{u}$ središtu bio karakterističan i za gradsku kuću orijentalnog tipa, on je bio svojstven i klasičnoj renesansnoj palati, zbog istih korena ovog prostornog tipa - antičke kuće sa unutrašnjim dvorištem, koje se transformisalo u zatvoreni prostor kroz dve etaže sa unutrašnjim stepeništem i galerijama. U spoljašnjem i unutrašnjem oblikovanju, koje je bilo relativno skromno i racionalistički svedeno, takođe je praćena klasična renesansna tradicija. Ravno malterisane površine fasada, bez profilisanih venaca, oživljene su samo horizontalnim nizovima otvora, sa polukružnim lukom, arhivoltama, u prizemlju i pravougaonim, arhitravnim, na spratu, ukrašenim plitkim nišama, lunetama, sa sedlastim orijentalnim lukom. Smirena monumentalnost izgleda bila je dopunjena reprezentativnim balkonom na konzolama ispred tri centralna otvora pristupnog pročelja, potpuno u skladu sa klasičnom simetričnom renesansnom kompozicijom. [12: 41.]

Nakon odlaska Romite iz kneževe službe, u kući je živeo njegov zet, dr Silvester Bartolomeo Kunibert iz Torina, koji je za pašinog lekara došao u Beograd iz Carigra- 
da 1826. godine, Ubrzo je prešao u kneževu službu. [10: 171-172.] Pored toga, on je obavljao dužnosti opštinskog lekara od 1832. do 1839. godine, kada je nakon odlaska kneza Miloša sa vlasti napustio Srbiju. [9: 24.] Doktor Kunibert je pre toga zgradu ustupio knezu Milošu, zbog velikih troškova održavanja (1837). [2: 142.] Sredinom XIX veka planirano je da se oko Doktorove kule načini javna bašta, ali je ona ustupljena za Bolnicu za duševne bolesti - Dom za s'uma sišavše, osnovan 1861. godine (i danas je zgrada u sklopu Psihijatrijske bolnice dr L. Lazarević, ulica Kneza Miloša 103). [3: 65.9: 70.]

Tokom tridesetih godina XIX veka je podignut samo mali broj najznačajnijih državnih zdanja. Na to su uticali nerazvijenost državnog aparata, nerazvijena legistlativa, ograničena finansijska sredstva, problem sa nabavkom građevinskog materijala i nedostatak graditelja. O svim pitanjima izgradnje odlučivao je knez Miloš, koji je neposredno odobravao planove, davao upustva nadzornicima državne gradnje, kontrolisao trošenje sredstava iz državne kase, birao graditelje i materijale, i sl. [13: 245-246.]

Kako je srpska kneževina dobila mogućnost osnivanja prvih vojnih jedinica, kada je 1835. godine predloženo šest popečitelja, među kojima je bio i popečitelj vojeni dela, u čiji je delokrug spadala i briga o zdravlju vojnika i stanju bolnicama. Međutim, umesto popečiteljstva formirano je Vojeno Policajna Kancelarija i stajaća vojska sa 1.500-2.000 vojnika. [8: 796. 14: 175.] Stvaranjem regularne vojske bilo je neophodno formiranje sanitetske i bolničke službe, kao i izgradnja zgrada za njihov smeštaj. Pretpostavlja se da je u novopodignutoj pešadijskoj Velikoj kasarni u Savamali, čiji je gabarit ucrtan na Jankeovom planu iz 1842. godine (a delovi su sačuvani i danas u kompleksu stare zgrade Generalštaba u ulici Kneza Miloša), bila smeštena i prva zdravstvena ustanova u Beogradu - Soldatečki špitalj, odnosno garnizonska bolnica. [3: 83-84. 8: 796. 14: 175-176.]

Da bi se unapredio smeštaj vojske, ubrzo je preko puta Palilulskog trga, na mestu koje je izabrao knez ...kod velike česme, i to, prvo, zbog zdrave vode koje u izobilju ima, a drugo, zbog zdravog vazduha... [14: 177.] započeta 1837. izgradnja nove Palilulske kasarne, pod nadzorom kneževog glavnog graditelja Hadži Nikole Živkovića. Smatra se da je kasarna imala podužni gabarit, sa po pet soba sa svake strane, i da se nalazila na prostranom placu između današnjih ulica Takovske i Đušine. Pretpostavlja se da je u delu kasarne bio i špital. [8: 796.]

$\mathrm{Na}$ osnovu pojedinih istorijskih izvora može se smatrati da je istovremeno sa izgradnjom kasarne, u okviru palilulskog vojnog kompleksa, bila razmatrana i izgradnja posebne zgrade soldatečeskog špitala za stotinu bolesnika. [3: 84-85.] Prema arhivskim dokumentima, knez je aprila 1837. godine razmatrao planove špitala, koji je verovatno bio delo pančevačkog graditelja Franca Dobija. On je radio i projekte za zgrade u Savamali, i davao je sugestije o razmeštaju prostorija, smatrajući da nije zdravo smeštati kuhinju u sklopu zgrade. Tada je, verovatno po nalogu kneza, urađen novi plan zgrade, koji je načertao Valentin Mor, maor-majstor iz Pančeva; do kraja godine je $z$ danje špitalsko verovatno bilo i zidano i pokriveno. [16: 34.] 
Na kasnijim planovima Beograda, kao što je Zarićev plan iz 1878, (Plan Beograda udešen za potrebe beogradskih osnovnih škola, sastavio Stevan Zarić, inženjer. Izdanje Državne štamparije, 1878. godine, razmera, 1:4000, čuva se u Ratnom arhivu u Beču, G Ib, 56.) [4: 85.] kao jedan od prvih artikulisanih javnih urbanih prostora novih delova varoši izdvaja se trougaoni prostor Palilulskog trga, na kome je bila česma. (Slika 2) Naspram njega uočava se prostrani trapezoidni plac kasarne (danas oivičen ulicama Takovskom, Dalmatinskom i Đušinom) na kome su ucrtani gabariti više zgrada, od kojih je jedna većih dimenzija i ima

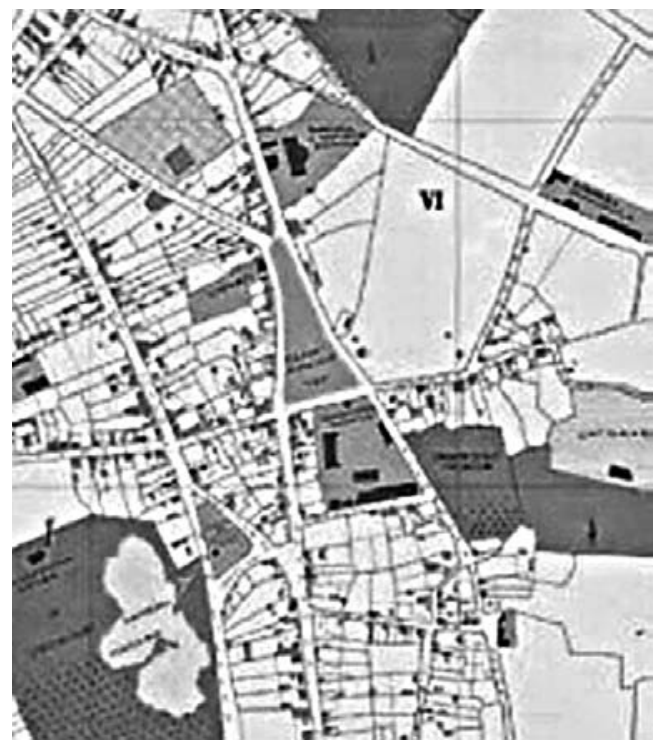
paravougaoni korpus sa dva bočna, neznatno izbačena krila. Ovaj oblik odgovara pojedinim prikazima bolnice na starim razglednicama sa početka XX veka, [17] na osnovu kojih saznajemo da je zgrada imala prizemlje i sprat, sa podužnim pravougaonim gabaritom na kome su se sa prednje strane isticala dva bočna rizalita, krila (možda sporedna stepeništa, jer je na jednom bio ulaz). (Slika 3) Zgrada je bila racionalne simetrične kompozicije glavnog pročelja, sa ulazom u središtu i nizovima dvokrilnih prozora, veoma skromnog oblikovanja, bez dekorativne obrade, osim horizontalnog međuspratnog venca. Prozori su grupisani po četiri i tri, verovatno su iza njih bile velike

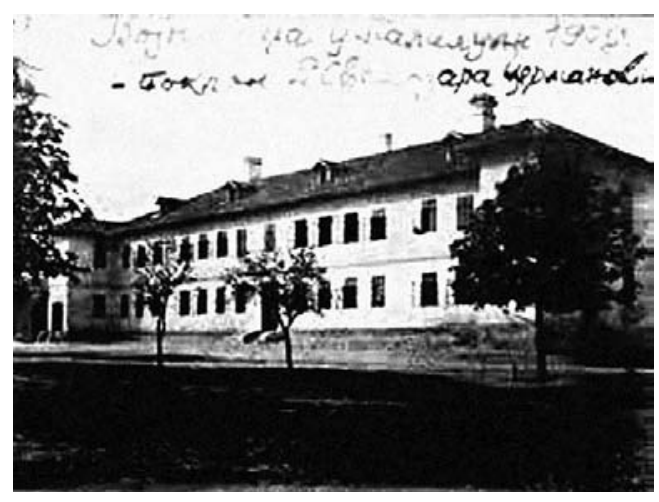
sobe za bolesnike, a nalazili su se sa obe strane centralne ose u kojoj je u prizemlju bio ulaz, a na spratu jedan prozor.

Mada su Palilulska kasarna i bolnica bile u blizini izvora pijaće vode, one nisu imale dobre higijenske uslove, o čemu svedoći epidemija tifusa iz 1838, zbog čega je bolnica iseljena i privremeno premeštena u novu zgradu Varoškog suda (kod Zelenog venca, u Jug-Bogdanovoj ulici), a zatim ponovo vraćena u Palilulsku kasarnu gde je zauzimala celu zgradu. [8: 796.14: 177.] Na osnovu sačuvanih dokumenata saznajemo da je Popečiteljstvo vnutreni djela predlagalo da se polovina zgrade ustupi građanskoj bolnici, ali se Glavni stab vojske tome usprotivio. Iz istih dokumenta znamo i da je zgrada na spratu imala 7 odeljenja, a u prizemlju 10 prostorija. [14: 177.]

Mada su Palilulska kasarna i bolnica očito imale određene građevinske i funkcionalne nedostatke, one su bile među prvim državnim zdanjima podignutim počet- 
kom XIX veka u novim perifernim delovima varoši i njihovom izgradnjom je iniciran kasniji razvoj i izgradnja celog Palilulskog kraja, posebno od početka šezdesetih godina kada je u blizini trga izgrađena i prva Varoška bolnica, a kasnije uređena i botanička bašta Velike škole - Jevremovac.

Krajem četvrte decenije XIX veka ostvaren je dalji napredak u ustrojstvu zdravstvene službe. Preduzeti su određeni napori za prikupljanje novca kako bi se formirali fondovi za izgradnju škola i bolnica, te je 1837. ustanovljen špitaljski $i$ školski fundus. Ovaj fond je 1841. razdvojen na bolnički i školski. [14: 188.] Pored toga, 1838. je u sklopu Popečiteljstva vnutreni djela formirano Odjelenije karantinsko sa sanitetom, na čijem čelu je bio Slovak dr Karlo Pacek, kao šef vojnog i građanskog saniteta. Iste godine doneto je i Ustrojenije garnizone vojske, zakon o vojsci, koji je propisao da se na njenom čelu nalazi Glavni stab. U okviru štaba poslovima vojnog saniteta bavio se dr Emerih Lindenmajer, iz Banata, koji je shvatao neophodnost izgradnje nove savremene vojne bolnice. On je predložio Projekt ustrojenija špitalskog. [10: 172. 14: 175.] Osim njega, jedan od prvih lekara u državoj službi bio je i dr Jovan Stejić, iz Arada, koji se bavio poslovima saniteta. Dr Pacek je pripremio i Nastavlenije za okružne lekare i fizikuse, po uzoru na Austriju, ali je nakon smene dinastija 1842. godine napustio zemlju. [8: 794. 10: 173-174.]

\section{Izgradnja nove Vojne bolnice na Vračaru sredinom XIX veka}

U vreme kneza Aleksandra I Karađorđevića i Ustavobranitelja četrdesetih i pedesetih godina XIX veka dolazi do značajnih političkih promena, društvenih reformi i ekonomskog napretka. [9: 70-71.] Finansijsko jačanje države omogučilo je napredak na polju obrazovanja, nauke i kulture, kao i sprovođenje modernizacije zdravstvene službe. Njeno unapređenje je posebno bilo neophodno u prestonici, jer je zabeležen veliki priliv stanovništva, tako da je u odnosu na 12.963 žitelja 1838 . godine, već 1846. zabeleženo 14.386 žitelja. [5: 272.] Značajno je da je donet niz uredbi kako bi se prevazišlo izuzetno loše stanje i česte pojave epidemija zaraznih bolesti. Takođe su i novi propisi za bolničku i apotekarsku službu donekle poboljšali zdravstvenu situaciju, kao i uvećanje broja privatnih lekara, koji su dolazili iz Austrijske carevine, kao što je bio Slovak dr Karlo Beloni. [8: 795.10: 173.]

I u drugim oblastima, posebno u državnoj građevinskoj sluzbi, bio je izuzetno važan dolazak brojnih obrazovanih inženjera, Srba iz Vojvodine, Nemaca, Čeha, Slovaka, Italijana i drugih, koji su značajno doprineli ubrzanom razvoju i modernizaciji zemlje. Ipak, i pored izvesnog napretka izgrađen je mali broj novih državnih zgrada; među njima se izdvajala Nova vojna bolnica na Vračaru. [7: 28-34.] Knez Aleksandar I Karađorđević je februara 1844. godine doneo odluku da se ustroji špital centralne vojske koji će imati 78 kreveta za bolesnike i sobu za oficire, sa četiri kreveta. [17] (Slika 4) Planovi za sva državna zdanja izrađivani su u Odeljenju građevina Popečiteljsva vnutrenih dela, čiji je upravnik od 1845. godine bio prvi arhitekta u državnoj službi, Čeh Jan Nevole, obrazovan u Pragu i Beču. [15: 73-76. 18] Stoga se pretpostavlja da 
170

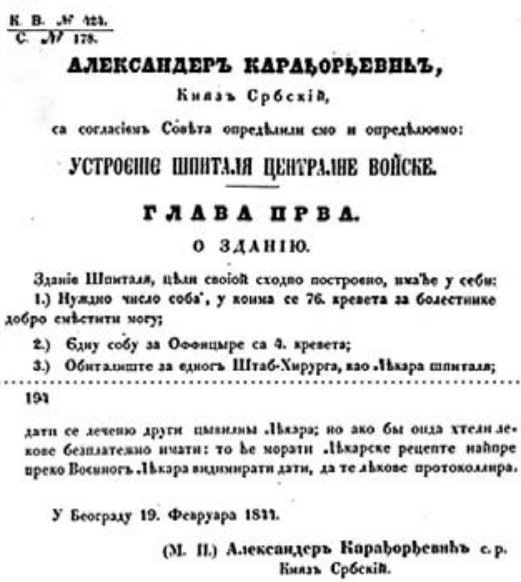

je on autor plana. Zgrada je podignuta između 1846 i 1849. godine kod Vračarskog trga, [3: 98.8: 796.14: 177-180.] a njen gabarit je ucrtan na već pomenutom Zarićevom planu iz 1878. godine, na velikom placu između današnjih ulica Svetozara Markovića, Njegoševe i Kralja Milutina, kod trougaonog Vračarskog trga (danas Cvetni trg). (Slika. 5) Još od vremena kneza Miloša, prostor između današnjih ulica Birčaninove, Kneza Miloša, Kralja Milana i Resavske bio je namenjen izgradnji vojnih zgrada, tako da su se tu nalazile sve značajne vojne ustanove Kneževine. Pored već pomenute Velike kasarne, naspram Vračarskog trga je bila Konjička kasarna (na prostoru današnjeg Parka Manjež), u blizini je bila Artiljerijska škola (između današnjih ulica Nemanjine, Kneza Miloša, Birčaninove i Resavske) i Tobdžijska kasarna (danas između ulica Kneza Miloša, Nemanjine, Sarajevske i Birčaninove). Koncentracija velikog broja vojnika na prostoru Vračara i Savamale, uticala je da se nova Vojna bolnica podigne u njihovoj neposrednoj blizini. Sama zgrada je bila slobodnostojeća, pomerena od ulice u unutrašnjost parcele i glavnim pročeljem orjentisana ka današnjoj Njegoševoj ulici.

Sačuvana istorijska građa ukazuje da je bilo planirano da se zgrada stavi pod krov 1846. godine, a da se 1847. završe ostali radovi. Plan zgrade je predviđao 7 soba za bolesnike, za oko 120 kreveta, kao i izgradnju veoma skupog kanala do Bare Venecije na obali Save (danas prostor Železničke stanice), kako bi se odvela kanalizaciju iz prohoda (klozeta). Takođe, kako bi zgrada bila što jeftinija trebalo je da se zidovi grade od mekog belog kamena sa Vračara i sa Tašmajdana. Izgradnja je koštala 27.000 dukata, a radove je izvodio bau-maister (majstor-zidar) Jovan Kriger. [3: 98, 100.14: 179-180.]

Veoma je značajno da su sačuvane šematizovane skice plana zgrade Vojničke bolnice u Beogradu, sa ucrtanim dimenzijama prostorija i legendom sa spiskom prostorija. Ovo je delo nepoznatog autora, a prvi put je objavljeno u knjizi dr Vladana 
Đorđevića Istorija srpskog vojnog saniteta, iz 1879. godine. [14: 178-179.] One predstavljaju veoma retke sačuvane planove i svedočanstva prostorne strukture javnih građevina nastalih sredinom XIX veka. Skice sadrže osnove donjeg i gornjeg boja, podruma, kapele, šupe i karaule, a na osnovu legendi sa popisom prostorija možemo da saznamo detalje o njihovoj nameni i rasporedu. (Slika 6) Zgrada je imala pravougaoni ulični korpus i dva bočna dvorišna krila, te u odnosu na oblik osnove pripada tipu kompaktnog razvijenog plana, a u odnosu na unutrašnju prostornu strukturu tipu kombinovanog podužnog plana. [19: 62-68]

BОगНИЧКА 6ОАНИЦА У БЕОГРААУ

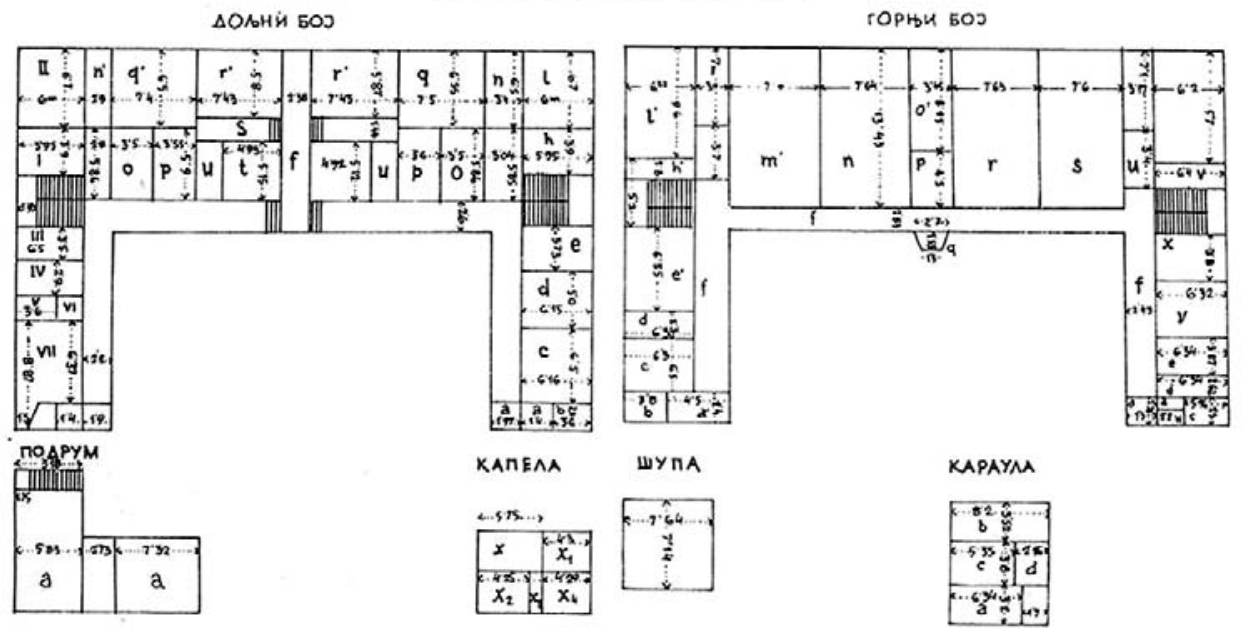

Ulični korpus, dužine oko $60 \mathrm{~m}$, imao je u prizemlju dva trakta prostorija, a na spratu jedan trakt, kao i podužni hodnik (konk), duž dvorišne strane, na oba nivoa. Bočna dvorišna krila su, takođe, u prizemlju i na spratu imala podužni hodnik (konk) sa dvorišne strane, iz koga se ulazilo u jedan trakt prostorija. Na spoju glavnog korpusa i bočnih krila bila su dvokraka stepeništa (basamci) za sprat (gornji boj). U prizemlju (donji boj) je bio ulazni hodnik (konk) koji je presecao po sredini glavni korpus, a iz njega se ulazilo u dva manja hodnika. Sa obe strane ulaznog hodnika su bile dve grupe manjih prostorija, iste strukture i namene - za bolesnike, za dežurnog lekara, apoteku, laboratoriju, kapelicu, kancelariju i sl. Oba krila prizemlja su sadržala pomoćne prostorije - kujnu, magacine, ćiler, kupatilo, perionicu i sl. Prohodi (nužnici) su bili na kraju dvorišnih krila, kao i u podrumu. Četiri velike sobe za bolesnike (širine oko 7,60 $\mathrm{m}$ i dubine oko 13,50 m) bile su na spratu (gornji boj), orjentisane ka ulici, a pored njih bilo je i nekoliko manjih soba za bolesnike. U spratnim krilima su bile sobe za lekare i za sluge. [14: 178-179.]

Mada na osnovu navedenih skica i opisa iz legende možemo zaključiti da je bolnica bila prostrana i sa većim brojem prostorija raznih dimenzija i namene (koje su obezbeđivale dovoljno prostora za preglede, smeštaj i lečenje bolesnika, lekare, magazine, apoteke, laboratorije, ali i kuhinje, perionice i sl.) prvi upravnik bolnice, dr Karlo Beloni, nije bio zadovoljan funkcionalnošću i higijenskim uslo- 
vima u zgradi. On je tvrdio: „... Spoljašnjoj simetriji zgrade svi su sanitarni propisi žrtvovani, po nameri upravnika tog preduzeća, arhi-Slavjanina, inženjera g. Nevole, koji je nami pravu nevolju napravio, jer je on, kao što je kazivao, hteo urnek slavenske arhitekture liferovati. Sljedstva te izredne namere jesu: rdava ventilacija, žalosni prohodi, nedostatak kupatila, takovi razpoložaj otvora vazdušnog grejanja $i$ sobni vrata, da vazduh jedne sobe sa onim druge komunicira, i črez to ne mogu se se izvesni bolesnici jedan od drugog izolirati, smrdljivi tremovi na gornjem boju ..." [14: 180.]

Na osnovu njegovih reči možemo zaključiti da je arhitekta Nevole svoju pažnju i graditeljsko umeće usmerio uglavnom na oblikovanje spoljašnjeg izgleda zgrade, a da, na žalost, novo zdanje vojne bolnice i pored reprezentativne arhitekture i monumentalnih razmera nije pružalo adekvatne higijenske i zdravstvene uslove za kvalitetno lečenje. Veliki problem, za razliku od starog Palilulskog špitala, bilo je odsustvo izvora pijaće vode u blizini, tako da je voda dovožena sakama (drvenim kolicima), što govori o lošem izboru lokacije za njenu gradnju.

Već 1864 . godine zgrada je bila zatvorena i temeljno renovirana da bi se otklonili navedeni funkcionalni i higijenski nedostaci, a bolesnici privremeno vraćeni $u$ stari špital. Nakon obnove, nova vojna bolnica je mogla da primi 150 bolesnika, ali su problemi sa snabdevanjem vodom i malim brojem sanitarnih prostorija ostali njen trajni nedostatak. [14: 180.]

Posebno su značajne zabeleške koje je ostavio dr Vladan Đorđević 1872. godine, u kojima opisuje glavne nedostatkenove bolnice, posebno ističući loš izbor mesta i nepostojanje izvora pijaće vode u blizini, što je bio razlog da se ogromna sredstva troše za njen dovoz; kao i na neuspešno kopanje arterijskog bunara. Pored toga, nedostaci su bili i loša ventilacija i odvod prohoda (nužnika), koji su doprinosili nesnosnom smradu leti. Pošto nije bilo kupatila na spratu, tamo su morale da se donose i odnose kade i voda za kupanje bolesnika. Iz Đorđevićevih zapisa takođe saznajemo da je bolnica imala samo 11 soba za bolesnike na spratu (od toga samo 4 velike za po 17 bolesnika), dok je u prizemlju bila administracija. Zbog nedostatka prostora za bolesnike, kasnije su i pojedine sobe u prizemlju adaptirane za njihov smeštaj. [14: 180-184.]

Na osnovu navedenog, vidimo da je u prvim decenijama ustrojstva nove srpske države u oblasti zdravstva pažnja posvećivana lečenju vojske, te bolnice namenjene garnizonu nisu podmirivale potrebe žitelja prestonice. Polovinom veka, prvo 1852, pa ponovo 1856, od strane prosvećenih odbornika beogradske opštine inicirana je izgradnja prve civilne bolnice. Međutim, kako nije bilo dovoljno finansijskih sredstava, Opštini je ustupljen stari oronuli Palilulski špital za privremeni smeštaj. [14: 177.]

\section{Izgradnja prve civilne bolnice u Beogradu}

Nakon ponovne promene dinastija i povratka Obrenovića na vlast krajem šeste decenije XIX veka, a posebno nakon uspostavljanja vlasti mladog kneza Mihaila, 
nastavljene su reforme državnih institucija, reforme vojske, modernizacija zdravstva, obrazovanja, nauke i kulture. U Beogradu se broj žitelja veoma brzo uvećavao, tako da je 1859. godine bilo 18.860 stanovnika, a 1867. godine čak 24.768. [5: 271, 274.] Stara utvrđena varoš je i dalje imala orijentalni izgled i bila je veoma zapuštena, jer tamošnje tursko stanovništvo nije imalo interesa da obnavlja svoje domove zbog nesigurne političke situacije, a protivilo se i njenoj regulaciji. Novo hrišćansko stanovništvo se uglavnom naseljavalo na obodima utvrđene varoši, u Savamali, na Zapadnom Vračaru, Zelenom vencu, Terazijama i Paliluli. [6: 8-12.]

Pored pokušaja podizanja prvih kulturnih ustanova, kakvo je bilo Pozorište na Zelenom vencu, knez Mihailo je posebne napore ulagao i u unapređenje zdravstvene službe i izgradnju prvih civilnih bolnica. [7: 35-43.] Izgradnji prve građanske bolnice u Beogradu je prethodilo podizanje bolnica u Majdanpeku, Knjaževcu, Kragujevcu, Kruševcu, Požarevcu i Šapcu. [3: 196-197.] Pri Ministarstvu unutrašnjih dela je osnovano vojno sanitetsko odeljenje, a značajno je bilo i donošenje Zakona o bolnicama i apotekama 1865. godine. Kako bi se prikupila sredstava za izgradnju i održavanje bolnica određen je i bolnički prirez, tako da svaki okrug obrazuje svoj okružni bolnički fond. Razvija se privatna lekarska praksa, a dr Stevan Milosavljević je 1855. godine bio prvi doktor medicinskih nauka, koji je titulu stekao na Pariskom univerzitetu. Pored toga pokreće se pitanje osnivanja sirotinjskog doma za socijalno ugrožene, obolele i iznemogle građane bez sredstava. [8: 794-795, 797-798. 14: 188.] Problem je bio i smeštaj duševnih bolesnika, za koje je 1860 . godine bio otvoren već pomenuti Dom za s’umasišavše u staroj Doktorovoj kuli na Guberevcu. [9: 70. 8: 798.]

Izgradnja Varoške bolnice je postala izvesnija tek 1861. Godine, kada je knez Mihailo poklonio zemljište i stare zgrade izvan utvrđene Varoši, kod Vidinske kapije, u istoimenoj ulici (danas ulica Džordža Vašingtona 19, ugao sa Palmotićevom) i neposrednoj blizini kompleksa stare Palilulske kasarne $i$ špitala, već korišćenih za potrebe opštinske bolnice. [14: 189] (Slika 7) Kako bi se bolnica izgradila, zemljište je donirao i bogati trgovac Ilija Milosavljević Kolarac, a u akciju prikupljanja priloga

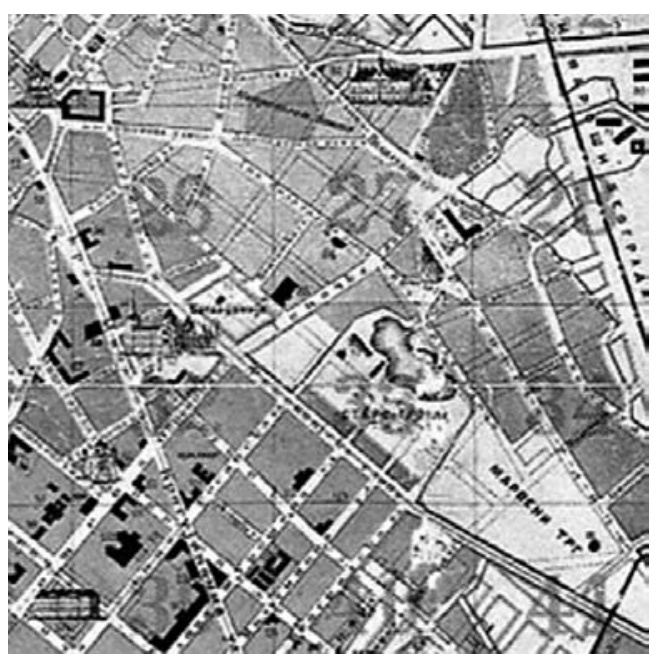
uključile su se i viđene građanke okupljene oko Odbora beogradskih žena pod predsedništvom kneginje Julije, koje su organizovale dobrotvorni bal za prikupljanje sredstava. Kamen temeljac je položen 30. juna 1865. godine u prisustvu kneza, državnih zvanica i građana. [8: 795-796. 14: 191] O ograničenim finansijskim sredstvima države govori i činjenica da je civilna bolnica, započeta prema planovima koje je državni arhitekta Josif (Jovan) Francl izradio 1855. godine, završena tek 1868. godine, prevashodno zahvaljujući dobrotvornim prilozima 
građana. Izvođenje radova je, nakon četiri licitacije, povereno tada najistaknutijem građevinaru Jozefu Štajnlehneru. [3: 196-197]

Prema opisu glavnog lekara dr Jovana Velente, Bolnica varoši i okruga Beograda je imala četiri odeljenja - po dva na svakom spratu. [14: 191. 9: 140.] Bolnica je građena kao slobodnostojeća dvospratna zgrada povučena od regulacije ulice, sa zatvorenom kubičnom strukturom, pravougaone osnove sa stepenišnom vertikalom izbačenom ka dvorištu. [15: 85. 20: 27.] (Slika 8) Prema unutrašnjoj prostornoj strukturi, sa jednim dubokim traktom prostorija ka ulici i podužnim hodnikom ka dvorištu, pripada tipu jednotraktnog podužnog plana. [19: 62-68.] U prizemlju je, duž središnje ose zgrade, bio ulazni hodnik i prostrano trokrako stepenište izbačeno ka dvorištu, oko koga su grupisane pomoćne prostorije sa nužnicima. $\mathrm{Na}$

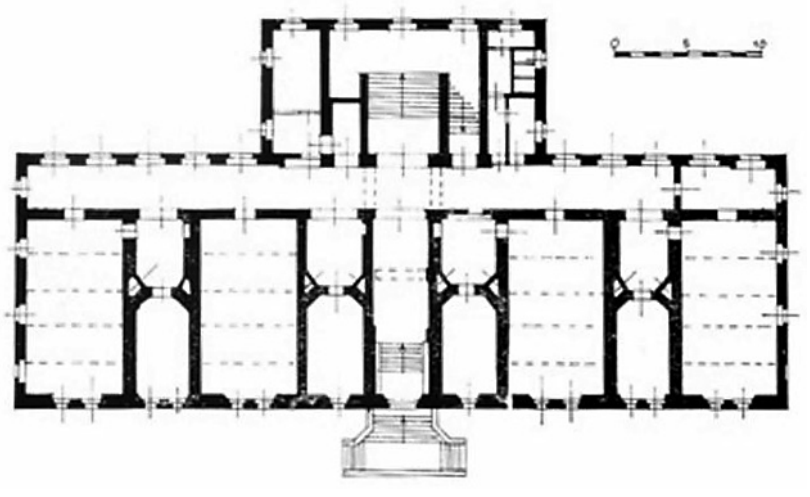
svakom nivou su bile po četiri sobe veće širine i dubine, koje su služile za smeštaj bolesnika, a do njih po dve manje povezane prostorije za bolničko osoblje i intervencije. U suterenu su bile kujna i perionica.

U oblikovanju spoljašnjeg izgleda zgrade ostvareno je skladno i uravnoteženo rešenje, koje uprkos primeni pojedinih klasičnih principa jasno izražava slobodu i dinamizam romantičarske kompozicije, inspirisane evropskim srednjovekovnim, romaničkim i gotičkim nasleđem. (Slika 9) Kod oblikovanja glavne fasade primenjena je klasična tročlana kompozicija sa centralnim blagim ispadom i dva bočna polja, ali se romantičarski pristup autora ogleda u njihovom tretiranju kao jedinstvenih vertikalnih polja, kao i u naglašavanju središnje vertikale i stremljenju u visinu izraženom kroz strelastu kulicu na trougaonom zabatu. Naglašavanje vertikala ogleda se i u primeni neogotički oblikovanih vertikalnih traka - lizena sa kulicama - fiolama. Uticaji nemačke arhitekture prepoznaju se i u formama profilisanog krovnog venca, sa specifičnim vertikalnim konzolicama i bogen-frizom sa pravougaonim zupcima, kao i formi prozora oblikovanih po ugledu na romaničke bifore. Po dva prozora su,

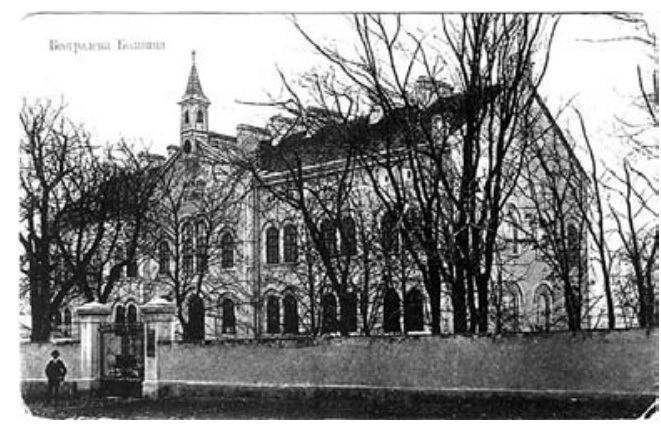
u gornjem delu, povezana polukružnim okvirima, koji podražavaju kameni slog, (u prizemlju) i profilisanim polukružnim vencima (na spratu). [7: 138-139.]

Međutim, i pored monumentalnih razmera i reprezentativnog izgleda, kod zgrade su, prema doktoru Velenteu uočeni brojni funkcionalni i higijenski nedostaci. Smeštanje kujne i perionice u 
suterenu je bilo veoma nepovoljno, jer se neprijatan miris iz njih širio po celoj zgradi, kao i iz prohoda (nužnika) pored stepeništa. [14: 191.] Ipak, i pored navedenih mana, stara Varoška bolnica ima posebni značaj i danas, ne samo zbog toga što je bila prva civilna zdravstvena ustanova u Kneževini, već je bila i jedna od malobrojnih građevina javne namene izgrađenih u prestonici tokom romantičarske epohe i svedoči o ostvarenom napretku u građevinarstvu, njegovoj modernizaciji i sleđenju tadašnjih stilskih tokova u srednjoevropskim centrima odakle su dolazili graditelji.

Značajno unapređenje zdravstvene službe je ostvareno i otvaranjem prve Javne ambulante u zgradi bolnice, kao i zbog činjenice da su u bolnici radili brojni doktori rođeni u Srbiji i školovani u Beču, Berlinu i Parizu. Takođe je na inicijativu dr Vladana Đorđevića, načelnika Sanitetskog odeljenja, 1872. godine osnovano Srpsko lekarsko društvo. Njegovim zalaganjem je donet Zakon o čuvanju narodnog zdravlja decembra 1879. godine, a nakon donošenja Zakona o bolnicama 1881, varoška $O p$ štinska bolnica je postala Opšta državna bolnica. [8: 798-799. 14: 191.]

$\mathrm{O}$ značajnom napretku zdravstvene službe od sedamdesetih godina XIX veka govore i napori da se adaptira i dogradi Vojna bolnica na Vračaru, kod koje su odmah po izgradnji uočeni brojni nedostaci. U knjizi dr Vladana Đorđevića Istorija srpskog vojnog saniteta, objavljenoj 1879. godine, prikazan je Projekt za preustrojenje i dogradu sadanje vojene bolnice u Beogradu iz 1875. godine. [14: 182, 185.] (Slika 10) Iz projekta, koji sadrži samo osnove novih zgrada, možemo zaključiti da je na slobodnom prostoru ispred i iza postojeće zgrade bila predviđena izgradnja šest no-

Пролект

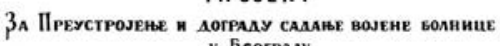
y Beorpany

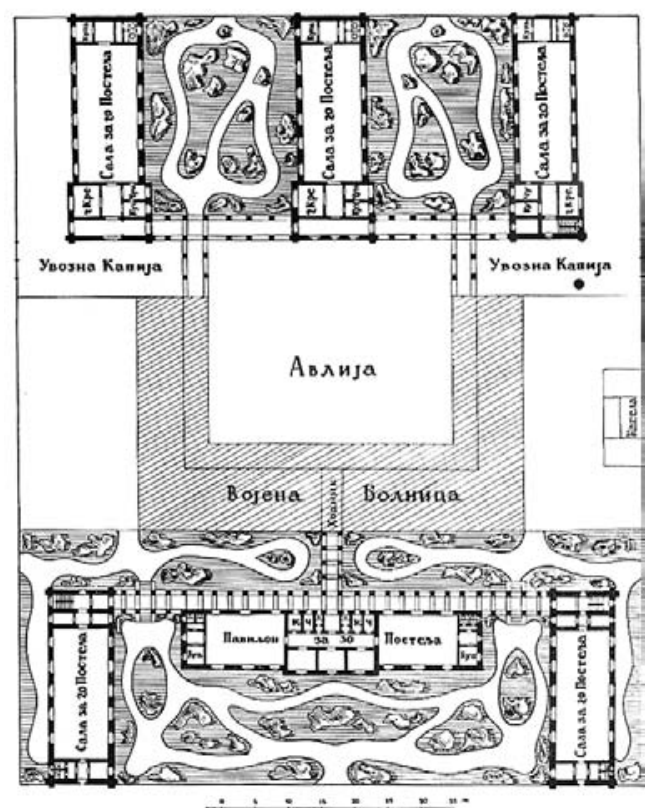

12 vih pravougaonih paviljona, koji su međusobno i sa ulazima i hodnicima stare zgrade povezeni natkrivenim tremovima - hodnicima sa stubovima, radi zaštite od sunca i kiše. Ispred postojeće zgrade, podužno, bila je predviđena nova prizemna zgrada sa direktnom vezom sa ulaznim hodnikom stare zgrade. Sa obe strane centralnog dela nove zgrade bile su sobe, sa ukupno 30 postelja, a na krajevima kupatila i toaleti. Pored centralne zgrade, na planu je prikazano još pet prizemnih paviljona (dve ispred, sa obe strane nove zgrade, i tri iza). Paviljoni su bili identične strukture, sa po jednom centralnom sobom za 20 bolesnika, i pomoćnim prostorijama, kupatilima i nužnicima na krajevima. Da je razmišljano i o unapređenju izgleda okolnog ambijenta bolničkog dvorišta i o ugodnom boravku bolesnika, govore uređeni 
vrtovi, sa stazama i zelenilom, prikazani oko novih paviljona. Mada nije poznat autor projekta, on je svakako bio školovani graditelj upoznat sa tadašnjim modernim konceptima bolničkih kompleksa zasnovanih na paviljonskom sistemu, jer predložena struktura paviljona, kao i njihovo povezivanje tremovima i uređenim vrtovima, $\mathrm{u}$ velikoj meri slede evropske idealne sheme i primere bolničkih kompleksa razvijanih od kraja XVIII veka. [21: 153, 155.] (Slika 11)

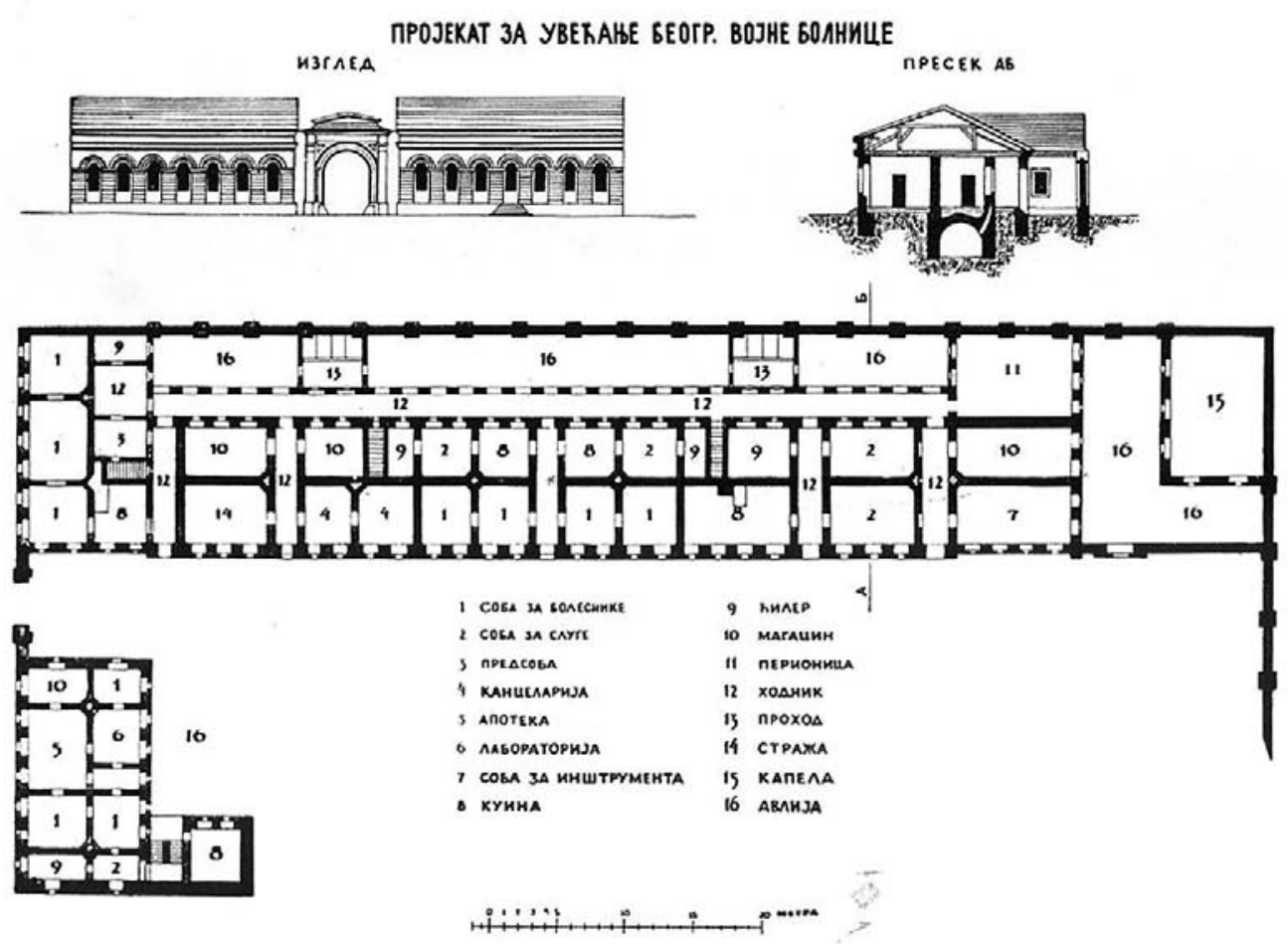

Pored ovog projekta sačuvan je još jedan, Projekat za uvećanje beogradske Vojne bolnice, koji pored osnova sadrži i izgled i presek. [14: 186.] (Slika 12) Za razliku od prethodno opisanog projekta, on je manje inovativan i prikazuje dve prizemne zgrade, složene tradicionalne strukture i svedene neoklasične arhitekture. Veća zgrada je imala podužni pravougaoni korpus i verovatno je bilo predviđeno da se gradi iza postojeće bolnice, celom širinom zadnje strane parcele. Nove zgrade su međusobno bile povezane reprezentativnom kapijom za kolski ulaz (verovatno iz današnje ulice Svetozara Markovića), a imale su dvotraktno podužno rešenje, sa dva niza prostorija različitih namena. Veća zgrada je imala podužni hodnik koji je bio orjentisan prema malim dvorištima (avlija), iz koga se pristupalo izdvojenim nužnicima (prohodi). Pored desetak relativno malih soba za bolesnike u dva trakta su bile predviđene kancelarije, apoteka, laboratorija, soba za instrumente, kujna, magacini, perionica i druge pomoćne prostorije, kao i kapela u izdvojenom dvorištu.

Verovatno zbog izbijanja rata 1876. godine, predviđeno proširenje Vojne bolnice nije realizovano, samo je izgrađen paviljon kneginje Julije Obrenović u dvorištu. 

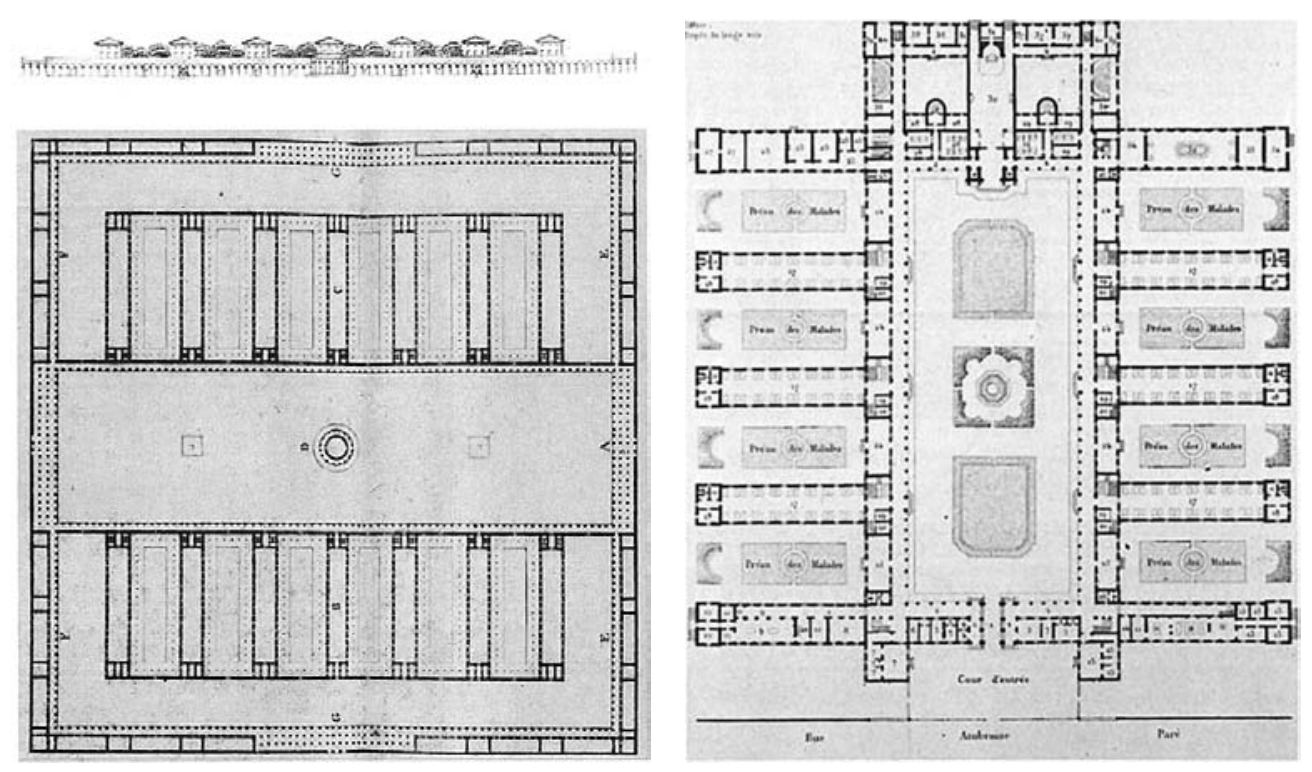

Zapisi lekara govore da je i 1889. godine stanje u bolnici bilo veoma loše, ali je ona napuštena tek 1904. godine, nakon izgradnje novog kompleksa. [14: 185, 187.]

\section{Nova vojna bolnica početkom XX veka}

Nakon proglašenja Kraljevine 1882. godine, a naročito početkom novog veka, ostvaren je konstantan napredak u svim oblastima života, a posebno u građevinarstvu. Zdravstvena služba je značajno modernizovana izgradnjom novih bolničkih zgrada za Opštu državnu bolnicu, koje se koncentrišu uglavnom na prostoru starog Vojničkog polja kod Laudonovog šanca, na padinama zapadnog Vračara ka Mokroluškom potoku (danas Bulevar Franše d' Eperea), gde su izgrađene: Ženska bolnica, spratna zgrada za Ginekološko-akušersko odeljenje 1902. godine; pet prizemnih paviljona Hiruškog odeljenja 1907. godine; zgrada za Prosekturu; paviljon za Dečje zarazno odeljenje; Grudno odeljenje 1913. godine; i dr. [8: 800. 14: 192.] Time je ovaj prostor predodređen za izgradnju polifunkcionalnog centra, površine preko 20 hektara, sa zgradama različitih socijalnih, zdravstvenih i obrazovnih namena, te su na njemu nakon Prvog svetskog rata izgrađene i druge bolničke zgrade. [6: 22-23, 28.]

Uslovi za izgradnju novih zgrada za kvalitetnije lečenje i smeštaj vojnih bolesnika poboljšali su se tek nakon dobijanja kredita 1903. godine, te je Glavna vojna bolnica podignuta između 1905. i 1909. godine prema planovima arhitekte Ministarstva vojnog Danila Vladisavljevića, obrazovanog u Minhenu i Ahenu (danas su u sklopu Kliničkog centra Srbije). [3: 373, 375, 377, 379. 14: 187. 15: 29-31.] Ona je zauzimala površinu od oko osam hektara (danas na uglu Pasterove i Resavske ulice) i predstavlja prvi moderni bolnički kompleks sa planskom kompozicijom, strukturiran po razvijenom paviljonskom sistemu koji je usvojen po ugledu na bolničke 
komplekse razvijane u evropskim državama. [6: 28, 43-44.] Izgrađene zgrade kompleksa nove Vojne bolnice prikazane su na Planu grada Beograda prestonice Kraljevine Srbije iz 1910. godine (Izrada Opštine beogradske, razmera 1: 10000, izradio Vasa Lazarević, čuva se u fondu Narodne biblioteke Srbije). [22: XVIII] (Slika 13) Celinu je činilo dvanaest jednospratnih zgrada - paviljona okruženih zelenilom, koje su činile jedinstvenu prostornu kompoziciju. Naglasak je bio

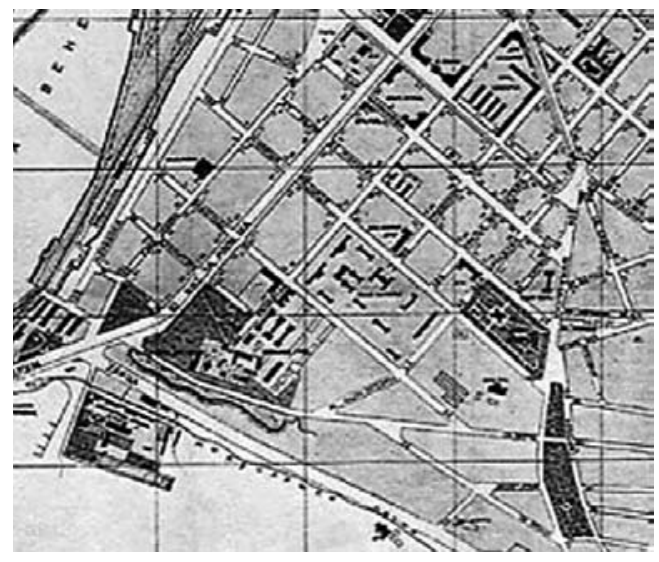
na pet zgrada orijentisanih ka Resavskoj ulici, koje su formirale akademski uravnoteženu simetričnu aksijalnu kompoziciju. Glavni ulaz, sa upravnom zgradom, nalazio se sa druge strane, u osovini Studeničke ulice (danas ulica Svetozara Markovića), a sama zgrada, sa centralnom kulom sa satom, bila je značajni urbani reper ovog dela grada. [6: 44.]

Bolnički paviljoni imali su različite oblike i dimenzije gabarita - pored kom-

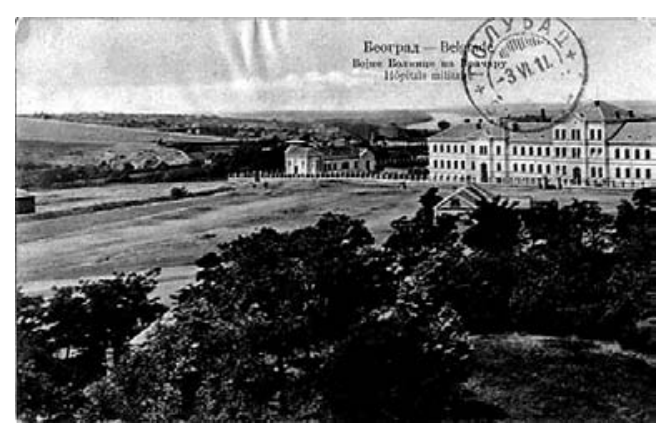
paktnih podužnih paviljona sa naglašenim centralnim ili bočnim rizalitima, izgrađeni su i složeniji razvijeni gabariti sa izbačenim centralnim ulaznim delovima i bočnim krilima - što je kompoziciji davalo složenost i monumentalnost. Smenjivanjem paviljona različitih oblika, međusobno postavljenih upravno i paralelno, formirana je slikovita prostorna kompozicija, zaokružena parkovski uređenim dvorištem, sa stazama i zelenilom. [3: 375, 377, 379.]

U oblikovanju spoljašnje arhitekture u neoromantičarskom maniru korišćeni su raznovrsni elementi tadašnje evropske arhitekture istorijskih stilova koji asociraju na srednjovekovne utvrđene zamkove, što je bio odraz želje autora da se u izgledu građevine iskaže njen vojni karakter. Iz tog razloga su na fasadama preovladavali elementi inspirisani srednjovekovnom fortifikacionom arhitekturom. Kao najreprezentativniji motiv kompozicije oblikovan je sam pristup kompleksu, sa trostrukom ulaznom kapijom koju flankiraju dve prizemne portirnice, ukrašene romaničkim elementima - plitkim

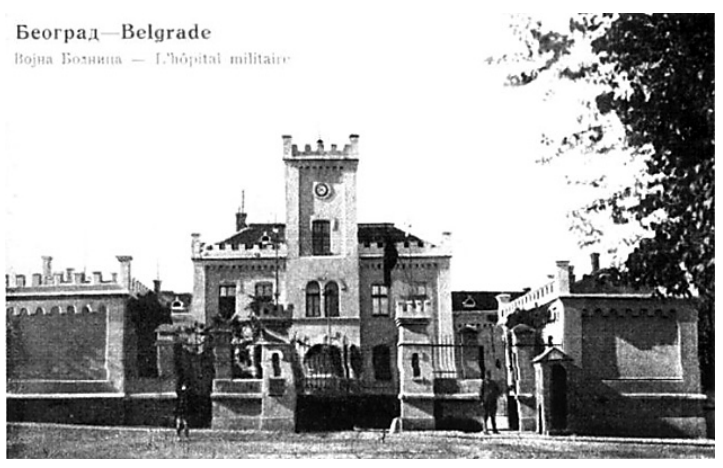


ugaonim lezenama povezanim frizom slepih arkadica i zupčastom krovnom atikom sa kulicama, u vidu srednjovekovnog grudobrana. Posebno pitoreskno oblikovanje je imala upravno-administrativna zgrada, sa centralnim rizalitom u obliku visoke srednjovekovne kule utvrđenog zamka. Slikovitost arhitektonskih oblika naglašena je kroz modelovanje krovnog venca sa frizom slepih arkadica i zupčastom atikom sa ugaonim kulicama. Karakteristična je i upotreba segmentnih lukova na prozorskim otvorima i neogotičkih profilisanih okvira i nadprozornih venaca.

\section{Zaključak}

Sagledavanje procesa izgradnje prvih bolničkih zgrada u Beogradu nakon obnavljanja srpske države govore o velikim teškoćama, ali i stalnim naporima da se zdravstvena služba uspostavi i da se obezbedi kvalitetno lečenje vojnika i građana, odnosno da se na polju zdravstvene kulture dostignu standardi srednjoevropskih zemalja, posebno Austrijske carevine. Arhitektura bolničkih zgrada bila je prevashodno podređena funkcionalnom i utilitarnom karakteru zdanja, te su iz tih razloga, kao i zbog relativno lošeg finansijskog stanja države, bolnice do početka XX veka bile relativno skromnih razmera, prateći na veoma skroman način osnovne evropske stilske karakteristike perioda u kome su nastale. Vojna bolnica u kompleksu Palilulske kasarne imala je svedeno klasicističko oblikovanje, kao i sva druga državna zdanja nastala u vreme prve vlade kneza Miloša Obrenovića, tridestih godina XIX veka. Akcenat je bio na solidnosti i dugovečnosti zdanja, kao i njegovoj funkcionalnosti. I pored skromnog klasicističkog oblikovanja, nova državna zdanja podignuta u Savamali i na Paliluli zasnivaju novi evropejski lik perifernih delova grada koja se postepeno urbanizuju i predstavljaju kontrast zapuštenom stanju utvrđene Varoši, gde još uvek preovladava orijentalna arhitektura. Pored pravilnih urbanih blokova u novim delovima grada se začinju i prvi javni prostori, kao što je bio Palilulski trg sa česmom u blizini Palilulske kasarne.

Daljim razvojem i osnaživanjem države polovinom XIX veka, posebno nakon dolaska prvog obrazovanog arhitekte Jana Nevole za glavnog državnog inženjera, kvalitet izgradnje državnih zdanja se znatno popravlja, ali na žalost nova Vojna bolnica na zapadnom Vračaru, zbog nedostatka izvora pijaće vode i drugih funkcionalnih nedostataka, nije doprinela unapređenju vojne zdravstvene službe. Ni prva civilna bolnica izgrađena šezdesetih godina kod nekadašnje Vidin kapije nije ispunila očekivane higijenske i funkcionalne zahteve za kvalitetno lečenje. Ipak njena arhitektura je bila značajan doprinos romantičarskom oblikovanju, u skladu sa tadašnjom srednjoevropskim stilskim tendencijama, i svakako je u velikoj meri svojim monumentalnim slikovitim pročeljem obogatila ambijent Palilulskog trga.

Sačuvani planovi za dogradnju Vojne bolnice na Vračaru, verovatno iz sedamdesetih godina XIX veka, svedoče o naporima da se bolničke zgrade unaprede i da se njihova prostorna struktura zasnuje na modernim evropskim teorijskim pristupima 
i praksi u oblikovanju bolničkih zgrada. Usvajanje paviljonskog sistema, sa zgradama okruženim zelenilom, doprinelo je da se početkom XX veka izgradnjom kompleksa Nove vojne bolnice na nekadašnjem Vojničkom polju ovaj deo grada predodredi za buduću Državnu bolnicu. Arhitektura i prostorna struktura celine, koja je pratila savremene trendove u organizaciji modernih zdravstvenih kompleksa u Evropi, predstavljala je značajan pomak u poboljšanju kvaliteta zdravstvenih ustanova ne samo u Beogradu, već i u celoj Srbiji. O dostignutom kvalitetu izgradnje i značajnom napretku koji je učunjen napolju zdravstvene arhitekture govori i činjenica da zgrade kompleksa Vojne bolnice i danas imaju istu namenu.

\section{Reference}

1. Stojančević V. Srpska nacionalna revolucija i obnova države od kraja XVIII veka do 1839. Istorija srpskog naroda, V-1. Beograd; 1981.

2. Vujović B. Umetnost obnovljene Srbije, 1791-1848. Beograd; 1986.

3. Nestorović B. Arhitektura Srbije u XIX veku. Beograd; 2006.

4. Maksimović B. Urbanizam u Srbiji. Beograd; 1938.

5. Radovanović M. Demografski odnosi 1815-1914, Istorija Beograda, knj. 2. Beograd; 1974.

6. Maksimović B. Ideje i stvarnost urbanizma Beograda 1830-1941.Beograd; 1983.

7. Roter M. Arhitektura građevina javnih namena izgrađenih u Beogradu od 1830-1900. godine, magistarska teza. Arhitektonski fakultet, Beograd; 1994.

8. Stanojević V. Zdravstvena služba, Istorija Beograda knj. 2. Beograd; 1974: 798-804.

9. Andrić N, Antić R, Veselinović R, Đurić-Zamolo D. Beograd u XIX veku. Zagreb; 1968.

10. Stanojević V. Organizatori zdravstvene službe i istaknuti bolnički lekari starog Beograda. Godišnjak grada Beograda. 1962-1963;IX-X:171-198.

11. Minić O. Problem očuvanja arhitektonskog i urbanističnog nasleđa Beograda. Godišnjak Muzeja grada Beograda. 1956;III:261-272.

12. Roter-Blagojević M. Stambena arhitektura Beograda u 19. i početkom 20.veka. Beograd; 2006.

13. Roter-Blagojević M. Pojava prvih zakonskih propisia i standard u oblasti građevinarstva u Srbiji tokom 19. i početkom 20. veka. Izgradnja. 1998;52:245-258.

14. Stanojević V. Najstarije bolnice u Beogradu. Godišnjak grada Beograda. 1960;7:175-195.

15. Đurić-Zamolo D. Graditelji Beograda 1815-1914. Beograd; 1981, ponovljeno izdanje 2011.

16. Kolarić M. (ed.) Klasicizam kod Srba, knj. 2. Građevinarstvo. Beograd; 1966.

17. http://www.vma.mod.gov.rs/vma-u-proslosti, pristupljeno 20.5.2014.

18. Roter Blagojević M. Jan Nevole, prvi moderni arhitekta u Beogradu. Stranci u Beogradu, Limes plus. 2014;1.

19. Roter M. Osnovna tipologija građevina javnih namena izgrađenih u Beogradu od 1830. do1900. godine. Arhitektura i urbanizam. 1997;4:62-68.

20. Gordić G. Arhitektonsko nasleđe Beograda, I. Beograd;1966. 
21. Pevsner N. A History of Building Types. London; 1976.

22. Vukotić-Lazar M, Lalošević M. (ur.) Beograd u mapama i planovima od XVIII do XXI veka. Urbanistički zavod Beograda, Beograd; 2010.

\section{Summary}

The aim of the paper is to give an overview of how the first health care buildings were erected in Belgrade, highlighting their significance in the modernization of the country, while reaching the European standards in that specific area of public life. Apart from the most important state buildings in Savamala - the Council, the Court and the Great Barracks, in 1837, Prince Miloš Obrenović starts with the construction of the Palilula Barracks near the Palilula Square. At the same time, he brings up an issue of the soldiers' hospital within the complex, with a capacity of one hundred patients. Thus begins a history of constructing the first hospital buildings. They are located in the peripheral areas of the Town, suitable for the health care buildings because of their position on the slopes towards the Danube and the vicinity of good quality water. The Palilula Military Hospital design was probably the work of Valentine Moor, a master builder from Pančevo. Not long after that, in the late 1840s, at the time of Prince Aleksandar I Karađorđević, preparations for building a new Military Hospital in Belgrade are underway. The design was probably the work of the main engineer, an architect, Jan Nevole. The hospital was built in the 1846-49 period, consisting of a ground and the first floor. The period of Prince Mihailo, like those of his predecessors, is marked by the construction of a hospital, the first civilian healthcare institution in the capital. On his land plot in Vidin Street, near Palilula Square and the erstwhile Barracks, in 1868, the Town Hospital was built according to the design of the state engineer Joseph Francl. The new Military hospital, designed by architect Danilo Vladisavljević, educated in Aachen, was constructed in 1905-09. At the West Vračar area, according the modern spatial organization with pavilions surrounded by greenery. The construction of first hospital buildings tells us about the endeavors of the Serbian Principality to reach standards of the developed European countries in the field of healthcare culture. The paper analyses building conditions, urban and architectural characteristics of the said buildings, as well as their impact on defining the character of the surrounding space, providing the foundations of a modern European image of the capital.

Rad primljen: 2. 7. 2014.

Recenziran: 29. 7. 2014.

Prihvaćen: 16. 8. 2014. 